\title{
melarete and peech: preface to an international philosophy with children collaboration 1
}

\author{
michael burroughs ${ }^{2}$ \\ penn state university - united states of america \\ luigina mortari ${ }^{3}$ \\ university of verona - italy
}

\section{abstract}

In this paper we discuss two research programs - MELARETE (Verona, Italy) and Philosophical Ethics in Early Childhood (PEECh) (State College, Pennsylvania, USA) and an emerging international research collaboration based on the benefits of practicing philosophy for meaning in early and middle childhood education. We argue for the good of philosophical thinking and its benefits to young students, with a particular focus on ethical development and meaning. We contend that through philosophical pedagogy we can make learning, meaning, vital to students. This is particularly relevant when dealing with questions of ethics and virtue, questions that are close to the lives of children from their earliest years. By discussing these questions and advancing philosophical ethics and virtue programs philosophers can play a central role in the development of responsible and ethical persons in the world. In order to do this, we contend, it is important that philosophy be introduced to children from a young age, in the early stages of schooling. Following a discussion of our respective research and education programs in Italy and USA, we discuss our current and ongoing plans for an international research collaboration on ethics and philosophy with children.

keywords: ethics; virtues; education; philosophy with children.

\section{melarete y peech: prefacio a una colaboración internacional en filosofía con niños}

\section{resumen}

En este artículo discutimos dos programas de investigación - MELARETE (Verona, Italia) y Philosophical Ethics in Early Childhood (PEECh - Ética Filosófica en la Primera Infancia) (State College, Pennsylvania, Estados Unidos) - y una emergente colaboración internacional de investigación basada en los beneficios de la práctica de la filosofía por el sentido en la educación de primera y segunda infancia. Argumentamos en favor del pensamiento filosófico y sus beneficios para los estudiantes más jóvenes, con un particular foco en el desarrollo ético y el sentido. Sostenemos que a través de la pedagogía filosófica podemos hacer del aprendizaje, del significado y sentido, algo vital para los estudiantes. Esto es particularmente relevante al lidiar con cuestiones de ética y virtud, cuestiones que están próximas a las vidas de los niños desde sus años más tempranos. Mediante la discusión de estas cuestiones y adelantando programas filosóficos de ética y virtud, los filósofos pueden tener un papel central en el desarrollo de personas responsables y éticas en el mundo. Para lograr esto, sostenemos que es importante que la

\footnotetext{
${ }^{1}$ The authors express special thanks to Tugce B. Arda Tuncdemir and Alessia Camerella for their assistance in the development of the research collaboration discussed in this article. We also thank our many collaborators - including administrators, teachers, and children - that have made this project possible.

2 E-mail: mdb32@psu.edu

${ }^{3}$ E-mail: luigina.mortari@univr.it
} 
filosofía sea introducida a los niños desde una edad temprana, en las primeras etapas de la escolaridad. Siguiendo una discusión de nuestros respectivos programas de investigación y educación en Italia y Estados Unidos, discutimos nuestros actuales planes para una colaboración internacional en la investigación en ética y filosofía con niños.

palabras clave: ética; virtudes; educación; filosofía con niños.

melarete e peech: prefácio de uma colaboração internacional em filosofia com crianças

resumo

Neste artigo discutimos dois programas de pesquisa - MELARETE (Verona, Itália) e Philosophical Ethics in Early Childhood (PEECh - Ética Filosófica na Primeira Infância) (State College, Pennsylvania, Estados Unidos) - e uma colaboração internacional de pesquisa emergente baseada nos benefícios da prática de uma filosofia significativa na educação de primeira e segunda infância. Argumentamos a favor do pensamento filosófico e seus benefícios para os estudantes mais jovens, com um foco particular no desenvolvimento ético e significativo. Sustentamos que através da pedagogia filosófica podemos fazer da aprendizagem e do sentido algo vital para os estudantes. Isso é particularmente relevante ao lidar com questões de ética e virtude, questões que estão próximas às vidas das crianças desde seus anos mais iniciais. Mediante a discussão dessas questões e adiantando programas filosóficos de ética e virtude, os filósofos podem ter um papel central no desenvolvimento de pessoas responsáveis e éticas no mundo. Para conseguir isso, sustentamos que é importante que a filosofia seja introduzida às crianças desde uma idade inicial, nas primeiras etapas da escolaridade. Acompanhando uma discussão de nossos respectivos programas de pesquisa e educação na Itália e nos Estados Unidos, discutimos nossos planos atuais para uma colaboração internacional na pesquisa em ética e filosofia com crianças.

palavras-chave: ética; virtudes; educação; filosofia com crianças. 
melarete and peech: preface to an international philosophy with children collaboration

A life without meaning is a kind of living death.

-Hannah Arendt, The Life of the Mind

In The Life of the Mind (1971) Hannah Arendt discusses a long-standing distinction in Western philosophy, present from the Ancients to the Moderns, between the activities of thinking and knowing (ARENDT, 1971, p. 14). These activities are distinguished, in part, by their respective ends, meaning and truth. Addressing the distinction as found in Kant's Critique of Pure Reason, Arendt writes:

The intellect (Verstand) desires to grasp what is given to the senses, but reason (Vernunft) wishes to understand its meaning. Cognition, whose highest criterion is truth, derives that criterion from the world of appearances in which we take our bearings through sense perceptions... But that is by no means the case with meaning and with the faculty of thought, which searches for it; the latter does not ask what something is or whether it exists at all - its existence is always taken for granted - but what it means for it to be (ARENDT, 1971, p. 57).

As discussed by Arendt, the desire to know is associated with science and empirical investigation. It is connected to common sense reference to and interrogation of that which appears to our senses. Since the $16^{\text {th }}$ and $17^{\text {th }}$ centuries, knowing, in this scientific, common sense, has led to many discoveries and advances in our society. Our lives are impacted on a daily basis by the fruits of this knowing, both due its material products and its status as a dominant episteme.

Alternatively, the desire to think, and for meaning, is associated with philosophy and contemplation. ${ }^{4}$ No such (scientific) progress and material advantage can be credited directly to the philosophical pursuit of meaning. Questions of meaning are, ultimately, unanswerable (in any final sense) and, so, are bound to disappoint the individual, or society, solely committed to commonsense empirical investigation and corresponding truths. Philosophical

\footnotetext{
${ }^{4}$ The two activities under consideration here (knowing and thinking) are related as opposed to completely separate. For one, the unanswerable questions derived from thought can motivate and drive the desire for knowledge, and, once found, knowledge can assist in defining the proper boundaries of contemplation and what is or is not answerable.
} 
contemplation and its goods of the mind are, as Bertrand Russell (1999) notes, without value for the "practical man".

In our contemporary age, philosophy has also been critiqued as lacking value for the "practical" ends of education, ends that prioritize technical skills in the sciences or learning as documented through standardized testing above the dialogue, open questioning, and reflection that are characteristic of the philosophical process. In contemporary education there is often little space for philosophy and the search for meaning, nor the time needed for robust philosophical dialogue in classrooms. Philosophical approaches to education and learning are often deemed "unimportant" or are overlooked.

But in education, as in the world more generally, there are several senses of "important" - there is material importance (e.g., the role of education in accomplishing professional ends); there is scientific importance (e.g., the role of education in securing knowledge); and, among others, there is philosophical importance (e.g., the role of education in providing meaning). In this paper we discuss two research programs - MELARETE and Philosophical Ethics in Early Childhood (PEECh) - and an emerging international research collaboration based on the benefits of practicing philosophy for meaning in early and middle childhood education. We do not argue that material ends and scientific learning are unimportant; however, these areas of education are already well represented in contemporary classrooms. Thus, in opposition to the dominance of these ends, we argue for the good of philosophical thinking and its benefits to young students, with a particular focus on ethical development.

We contend that through philosophical pedagogy we can make learning, meaning, vital to students. This is particularly relevant when dealing with questions of ethics and virtue, questions that are close to the lives of children from their earliest years. By discussing these questions and advancing philosophical ethics and virtue programs philosophers can play a central role in the development of responsible and ethical persons in the world. In order to do this, we contend, it is important that philosophy be introduced to children from a young age, in the early stages of schooling. While philosophy is already common 
in many classrooms for adolescents, it is much more rarely introduced in early to middle childhood, ages 3-10. Given this relative lack of representation it is important for us to conceive of possibilities for philosophical education in early and middle childhood education. In this article we will discuss two approaches to practicing philosophy with children - in connection with virtue and ethics education programs in Italy and the United States - and a developing international collaboration to advance research on philosophy, ethics, and virtue education in early and middle childhood education.

\section{i. early and middle childhood education}

There are at least two broad purposes in early and middle childhood education. First, there is a purpose to help children develop essential skill sets (academic, civic, social, and emotional) that are to their advantage both as children and as future adolescents and adults. Second, there is the purpose of cultivating the continuing love of learning, the desire to continue to learn that, ideally, will carry children through their schooling and beyond.

We propose a third purpose in early and middle childhood education: the pursuit of meaning. For the purposes of this article we are focusing on "ethical meaning," or, the discovery of the central place of ethics and virtue in life and the development of relevant motivations and skill sets. Children are well placed to grasp ethical meaning in their own lives. Indeed, contemporary research has demonstrated that children, from a young age, possess the capacity for ethical reasoning and judgment (NUCCI, 2001; SMETANA, JAMBON, \& BALL, 2014). In addition, several studies on the impact of philosophical education in early and middle childhood have shown the ethical concerns and abilities of children. For example, Backman et al. (unpublished) discuss advances in the ethical reasoning and judgment of 7-8 year old children following a philosophical education intervention involving discussion of stories and accompanying drawing activities; Schleifer et al. (2003) discuss the impacts of philosophy on moral judgment, empathy and emotion recognition in early childhood, showing that children's moral development and judgment can benefit from regular philosophical 
discussion in classrooms; and Gardner (2012) shows the impact of philosophical discussion on children's ability to increase perspective taking, be comfortable with ambiguity, and adopt broader, less ego-centric perspective taking.

In addition to these studies, and several others, that show the positive support that philosophical work can provide for developing children, we, as philosophers and educators, also contend that children have much to offer to us and can impact our discipline and research programs. Children have a sincere interest in philosophical questioning, exploration, and discussion. Children search for meaning and can illustrate to adults the importance - and the potential for joy and excitement - in this process. In the ethical domain, children experience distinct issues of navigating their world, social relationships, and conflicts, all while developing the necessary ethical understanding and tools to do so. Thus, in our educational work with children we learn a great deal about the importance of philosophy in education, for children, and the distinct ways in which ethics is vital in the lives of developing children.

\section{ii. current project descriptions}

We now turn to discussion of our current projects - including their respective points of focus, philosophical orientation, and potential benefits for children - and the foundation for our prospective collaboration. To this end, we discuss our philosophy, ethics education and research programs in Verona, Italy, and State College, Pennsylvania, USA. Following this discussion, we consider areas of synergy for an international collaboration between our programs and possibilities for practicing and researching philosophical, ethical, and virtue education in early and middle childhood classrooms.

\section{i. melarete, verona, italy}

The MELARETE project is based on the pedagogical idea that a good educative approach must give children meaningful experiences capable of 
cultivating all dimensions of the person: cognitive, aesthetic, affective, ethical ${ }^{5}$, political and spiritual. MELARETE works to connect these aims through the ethical dimension of pedagogical work. Specifically, the project is based on the philosophy of care as pedagogical horizon (MORTARI, 2002; 2015) and connects this with the virtue ethics of Aristotle. In addition, MELARETE deploys a "research for children" epistemological framework (MORTARI, 2009) and a maieutical methodological approach, as inspired by the Platonic Dialogues.

\section{the melarete philosophy of education}

We start from the presupposition that each educative action must develop within a broader philosophy of life, a philosophy that characterizes essential aspects of human life. Since the human being, as referenced by Heidegger, is a "lacking being" (that is, a being that is not self-sufficient and does not possess sovereignty over its life) care become essential: we need care in order to safeguard, nourish, and repair life.

If care is essential in life then it is also important in education, as children, too, need care from adults if their possibilities are to flourish, and, also, children need to be educated to care for oneself and for others (NODDINGS, 1984). If we further develop a phenomenological analysis of care we can find that the core of care is ethical, since what motivates the disposition to care is the search for the good life (MORTARI, 2015). We contend that to be moved for the desire for the good is a primary virtue that, in turn, calls for us to act with other virtues such as respect, responsibility, generosity, courage, and patience. If care has an ethical core that is enacted through virtues, then an ethical education must be an education for virtues in the horizon of a philosophy of care. MELARETE is conceived on this

\footnotetext{
${ }^{5}$ The MELARETE project adopts the term "ethics" over "moral." Although there is no universally accepted distinction between the two terms, and they are often used synonymously, we follow Ricouer's (2007) distinction in which he defines two different aims: "ethics" has the task of comprehending "what is good to do" and "morality" is engaged in defining "what is right to do." This implies that ethics underlies the major question as to defining a good life and is more squarely situated in the Aristotelian tradition, while morality is more centered on defining rules and codes of conduct (and is more centered in the Kantian tradition). Ethics investigates primary questions and virtues for the good life and this is a primary focus of MELARETE.
} 
conceptual basis (melete, from Ancient Greek, means "care," and arete means "virtue").

In addition to and alongside caring, the human being is a thinking being; that is, a being that is called to reflect about life in order to find ways for authenticating existence. On this ontological assumption, we think that learning to think well is also essential, since only a thoughtful person could be a citizen capable of co-constructing with other citizens in a democratic community. One way to approach this in a democratic society is to educate the young to think in a Socratic way: to identify the most important questions for life and to investigate them with a radical and critical method. As Socrates reveals (for example, as characterized by Plato in the Apology and Phaedrus), important questions concern the search for what is good, beautiful and right in life. Indeed, what is most important for the human being is living a good life and a life is good only if the work of existing is inspired by the search for the "things of value for life": the good, the beautiful and the right. Since these are ethical questions, then, if we adopt the Socratic view of education, the core of the educative project is ethical in its essence.

\section{the melarete educative methodology}

The main reference for an ethic of virtues is Aristotle, for whom virtue is the disposition to orient action towards a good aim and in the right way (NE, II.6 1106b20-25). In this sense, virtue becomes the condition for searching for a good quality of life (eudaimonia) and this serves as the aim of ethical reflection (NE, I.1 1094a). Key to this aim is the assumption that to search for the good also requires one to act with virtue (NE, I.8 1099a15-16).

From a pedagogical point of view Aristotelian virtue ethics tells us that virtues are habits and can be learned through action. Many forms of character education are based on this theory, though, in some cases, they are limited by a conception of "virtues as inculcation": what is good and virtuous is already defined and, consequently, education must guarantee that learners acquire these predetermined ends. The limit of this approach consists in a violation of what we 
take to be a core of the educational process: to educate students to think in a radical and critical way.

In order to put into practice an education for virtues that is in accord with the human need for thought, a philosophy of education can take as reference Socratic paideia, since this puts maieutical dialogue at the center of the learning process and aims to develop a capability for thinking in the learner. If we put together the Aristotelian and Socratic perspectives, to organize an education for ethics of virtues means organizing contexts of learning where students can both practice virtues and reflect on virtues in order to grasp their specific essence. Without the possibility to acquire the discipline of thinking there is no education and without experiences that invite learners to act with virtues the learning process can be too abstract.

\section{the structure of melarete}

MELARETE involves children as researchers, that is, as subjects that search for and co-construct ideas in life and the educational process (and not merely as consumers of ideas established by others). We define the epistemological framework for this educational research project as "research with children," based on a prioritization of involving children in the research method. The research is guided by the intention to develop "children-centered research," an inquiry that improves children's experience. The educative project and research occurs in a relationship and has to be guided in an ethical way. From the perspective of "research with children" the researcher must listen to children as active participants and encourage them to give voice to their thoughts. Further, the researcher must respect their thoughts, avoiding imposition of ideas and instead orient children to frame and gain awareness of their ideas. Finally, the researcher must "give children time," that is, adopt a pace of research and interaction that is responsive to children's needs.

There are two main research questions at the root of our project and that structure our discussions with children:

(1) A Socratic question: "What is a virtue?" 
(2) An Aristotelian question: "How is it possible acquire virtues?"

By taking inspiration from Socratic maieutics our educative method is based on philosophical conversation on the ethical questions of virtues. As Arendt (1958) explains, human beings are at the same time singular and plural. Our plurality is evident since we need others for existing and only through relationships with others can our life flourish. Our singularity is evident when our conscience finds itself in dialogue even while in solitude. In order to grow in our humanity we need to cultivate both the capacity to think by oneself and with others. On these premises the project involves children both in "collegial" activities and in "singular" activities of thinking.

Collegial activities include:

- participating in philosophical conversations on the essence of a virtue

- reading, discussing, and inventing stories with ethical meaning

- discussing vignettes representing ethical dilemmas

Singular activities include inviting children to write a journal where they can narrate "virtuous actions," both in terms of their own actions and in the actions of others. In this way, each child creates her/his "journal of virtues" (see page 6 below).

Since, from a socioconstructivist perspective, we learn in relationships with others, the project foresees the organization of an educative situation in which the personal reflections each child writes in her/his journal are shared and discussed with other children. The educative situation then develops in this way:

(1) A child writes an account of virtue in the "journal of virtues";

(2) The child copies the name of the virtue on a sheet in the shape of a tree leaf;

(3) Each child takes her/his leaves and then attaches them on a paper tree in the classroom: this is the classroom "tree of virtues" (see page 6 below). The children regularly observe and discuss the virtues on the tree so as to consider ethical actions as understood and lived by the children.

The MELARETE project (with the activities as described above) has been realized in many schools in the North East of Italy for a duration of three years. In tandem with the educational project, a qualitative research project is 
implemented. The qualitative tools for gathering data include audiorecording and transcribing classroom philosophical conversations and reviewing and coding virtue journals.

\section{melarete - sample "journal of virtues" virtues"}

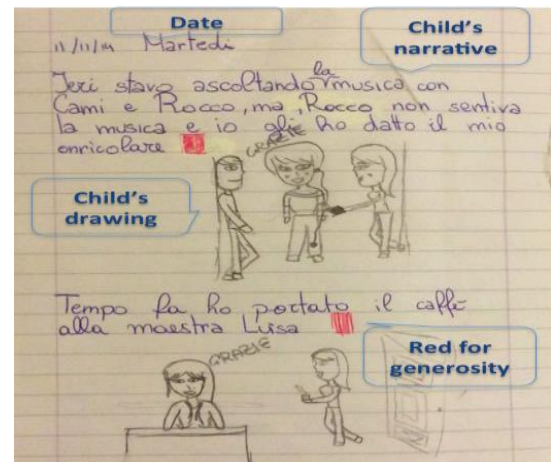

melarete - classroom "tree of

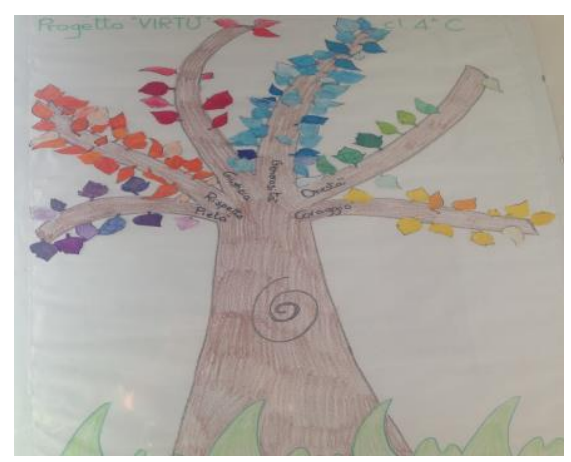

ii. philosophical ethics in early childhood (peech), state college, pennsylvania, usa

The Philosophical Ethics in Early Childhood (PEECh) project takes inspiration from three areas of research and education: philosophy with children; constructivist education; and social domain theory. Our goals in forming this project are to (1) better understand the ethical questions and concepts that are particularly salient in early childhood (ages 3-5 years) while providing a space in pre-kindergarten classrooms for philosophical discussion of these questions and (2) to research the developmental benefits of these discussions for young children as both ethical and philosophical persons. A fundamental aim of our project which informs both our educational approach and research methodology - is to provide children with ethical and philosophical recognition, that is, to begin our research from the premise that young children are developing, yet also-already philosophical and ethical persons (LONE, 2016). We contend that to recognize children as such (in our interactions, discussions, in the selection of our research 
and education materials), can itself be a positive support in the developmental process of young children.

\section{peech philosophy and psychology foundations}

We have benefitted from the philosophical and educational work of Matthew Lipman, David Kennedy, Walter Kohan, and others from the "philosophy for children" tradition, but use "philosophy with children" here as a broad classification for educational work with children based in dialogue and philosophical questioning. This approach takes many forms and can be practiced with children at any age level (from pre-kindergarten to secondary education and beyond), using discussion prompts of many kinds (children's literature, artwork, games, puppets, etc.) and diverse discussion topics (ranging from epistemic and metaphysical questions to ethical and social political questions, among others). In PEECh we adopt a philosophy with children approach that focuses primarily on ethical questions and concepts, such as fairness, empathy and perspective-taking, personal welfare (issues of harm to oneself and others), and issues of inclusion and exclusion in groups. Our discussion materials - short stories accompanied by puppet shows and a variety of child-centered extension activities - are intended to draw out the ethical and philosophical interests of pre-school children and make these points of focus for class discussion and consideration.

Alongside and related to this approach, our project is influenced by the constructivist education philosophy of John Dewey (1938). Dewey's influence on our project - and philosophy with children more generally - is vast. Two areas of Dewey's work are particularly significant for the framing of our project: theorizing the structure of educational experience in terms of the interaction of objective and internal conditions and, related to this, viewing successful and productive learning as building from the interests, attitudes, and motivations of young children. The objective conditions of an educational experience include the learning environment, broadly construed. The educator has some control in producing objective conditions (choice of materials, the classroom environment, the teaching methodology and approach of the educator, the social environment of the school, 
etc.). Internal conditions, on the other hand, include the students' own needs, attitudes, interests, and capacities. Combining these conditions in the learning process, Dewey argues that the two must reinforce each other such that objective conditions align with internal conditions to produce educative experiences, or, those that lead to growth. This is not an experience that can be fully generalized, but rather, requires cultivating an experience that has educative quality for particular children at a particular time. That is, to facilitate growth - the aim of educative experience, to produce interests, desires, and capacities that will motivate further learning - requires attention to the specific conditions and needs of a particular population of learners.

In PEECh, we adopt this philosophy by using a case-study research approach that does not seek to generalize our findings to pre-school children as such, but instead focuses on the ethical interests and development of this population of children (in a particular school and class). In addition, our educational work includes selecting materials (puppets, accessible stories, and child-centered extension activities) and a pedagogical approach (based in active listening and group discussion) that meet the interests and multiple communication styles (verbal and non-verbal) of pre-school children. Further, as noted above, our methodology begins from the premise that children are active participants in the construction of learning in the classroom and education must be vital for both student and teacher in order to be effective.

In addition, social domain theory - an area of moral developmental psychology - has been influential for the development of our project. After surveying the research that exists in philosophy with children we felt there was, and remains, a need to combine this research with significant research being undertaken in moral developmental psychology. A primary focus of our work has been to combine research on the educational and developmental import of philosophical work with children with current and highly influential research in moral developmental psychology, particularly in the work of social domain theory. This combination is central for at least two reasons: first, relevant developmental psychology can help us to better understand and develop 
educational curricula for young children and, second, philosophy with children can provide developmental benefits that, at this point, are rarely discussed in this literature. In our case, the result of this combination has been a project that utilizes the insights of moral developmental research with the educational approach of philosophy with children. In contrast to the still influential work of Lawrence Kohlberg which placed young children in the pre-moral realm, social domain theory has established that children as young as the age of three years make distinctly moral as opposed to social judgments (i.e. judgments pertaining to moral issues as opposed to social-conventional issues). In addition, social domain theory provides us with a developmental framework that regards children as developing morally, socially, and personally in distinct, yet, intimately related ways, while also providing useful conceptual distinctions between moral, social, and psychological domains of development (SMETANA; JAMBON; BALL, 2014).

\section{peech pilot research project}

After running a pilot iteration of our study at a pre-school $(n=30)$ in State College, PA, our program showed strong promise in terms of ethics education and developmental outcomes. Our 12-week education and research program was introduced in one classroom $(n=15)$ with a waitlist classroom $(n=15)$ continuing with regular lessons. We conducted pre- and post-interviews with children (both education and waitlist group) and pre- and post-interviews with lead teachers in both classrooms. Several other measures were used. ${ }^{6}$ Interviews with children focused on a series of ethical dilemmas prompted by brief stories and accompanied by drawings (for an example, see page 9 below). During education sessions, the lead facilitator introduced a brief story on an ethical theme and facilitated dialogue with participating children. These discussion sessions were followed by extension activities and discussion with small groups of children (3-4 persons) on the same philosophical and ethical theme.

\footnotetext{
6 Additional measures included structured classroom observation, pre- and post-parent questionnaires, and teacher questionnaires.
} 
Following our pilot study we saw significant advances between our education (PEECh) and waitlist/control groups including in children's articulation of ethical concerns, their ability to recognize and use "emotion markers" in response to stories (e.g. the ability to use and identify emotion terms such as "happy," "sad," "frustrated," etc.), and in their ability to provide justifications for and solutions in response to ethical dilemmas (see page 9 below). PEECh group children surpassed waitlist/control group children in each of these categories. Based on the success of this pilot program we are now refining our educational approach and curricula materials and developing a second iteration of the study in Lewistown, PA. In this study we are working with a larger group $(n=72)$ and will look to see if the benefits discovered in our first study are consistent in a different school, with different children from a low socioeconomic background.

The aim of this work is not just to understand the developmental impacts of philosophical work with children. For research purposes this is important enough, but we want to research for the advancement of philosophical and ethics education work with children in early childhood settings which, at this point, is very rare. When used in the USA context, philosophical approaches are more commonly deployed in middle and high school classrooms. And, yet, we have shown, in our first study, that philosophical and ethics education work with children can have significant developmental impacts. Ultimately, our goal is to support the formation of a philosophical ethics curriculum for use by teachers in pre-schools both in and beyond the United States.

\section{peech - sample illustration, story, and questions}

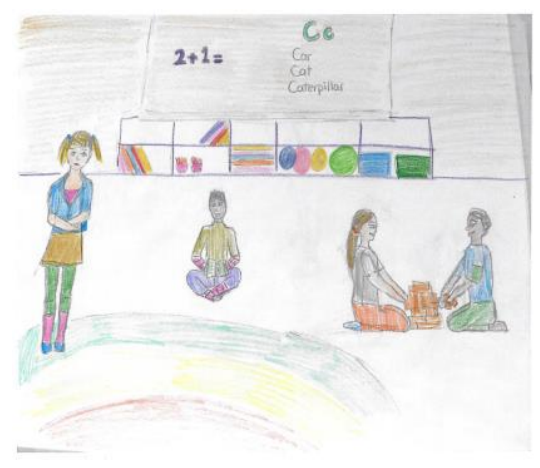

\section{The New Kid in Class}

Kristina's family just moved to town. She is starting her first day at her new school. She doesn't know anyone in her school and she feels shy and a little nervous. After getting dropped off at school by her parents, Kristina walks into her new class. She sees some kids playing games in one corner of the room. 
In another corner of the room she sees some kids drawing pictures of their favorite animals.

Kristina likes to play games and likes to draw, but she doesn't know anyone in class and she's not sure what to do. So, Kristina decides to stand by herself in another corner of the room. Some of the kids in class notice that Kristina is standing by herself.

\section{Questions:}

1. How do you think Kristina feels right now? Why?

2. What are some things the kids in class could do for Kristina? Why should they do those things?

3. How do you think Kristina will feel after the kids do those things?

peech - pre- and post-pilot study results

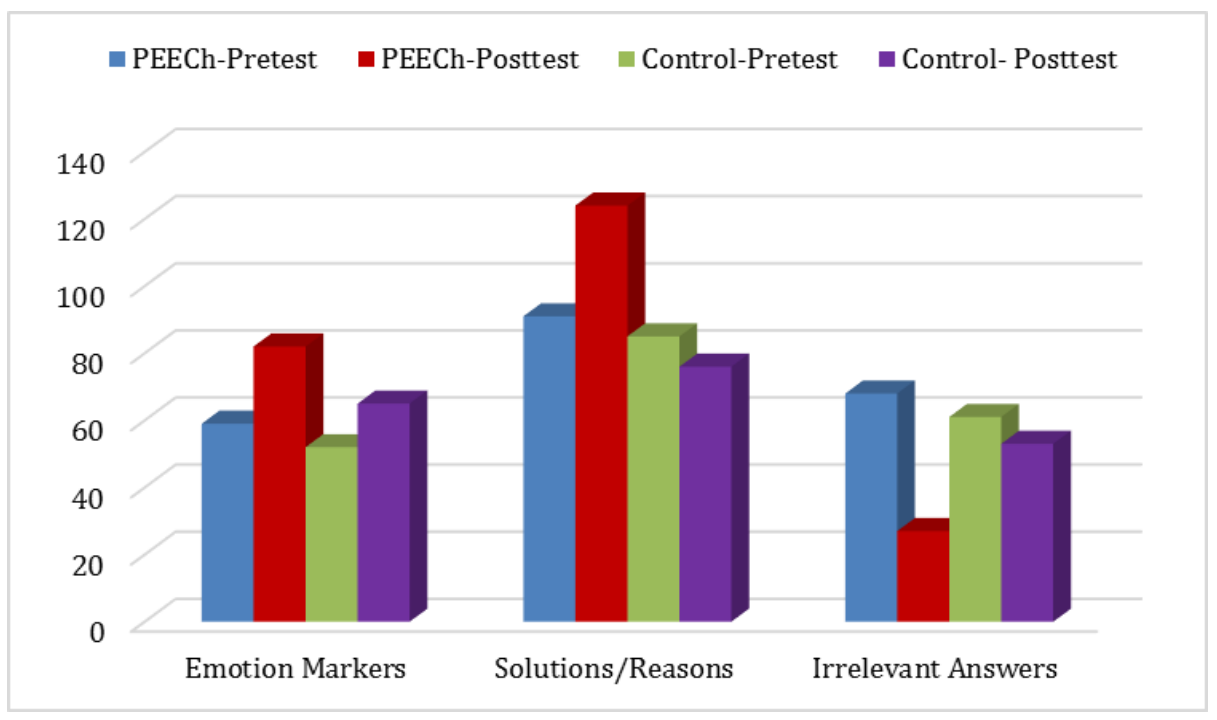

\section{iii. preface to an international philosophy with children collaboration}

As will be clear from preceding discussion, MELARETE and PEECh are distinct education and research programs, based in different parts of the world (Italy and USA). Our programs are also influenced by different, yet related, philosophical traditions, research methodologies, and epistemologies. However, upon reflection and significant discussion over the past two years (including several shared conference presentations), the authors have come to understand these differences as strengths for an international philosophy with children collaboration. For example, MELARETE has benefited from the early childhood focus of PEECh. After reviewing PEECh curricula and approaches to practicing philosophy with pre-schoolers in the USA, MELARETE is now developing an 
extension of its programming for pre-school classrooms. In addition, PEECh has benefitted from the MELARETE focus on combining philosophical and virtuesbased education. Following classroom visits in Verona, Italy, and review of MELARETE activities PEECh has adapted new lessons in the classroom modeled on the "journal of virtues" activities (see pages 5-6 above).

In addition to these productive differences, our programs share many areas of synergy that, we feel, can anchor a productive research collaboration going forward. First, both of our programs are committed to constructing ethical, and philosophically rich, curricula for children. Building on the contention that ethics is a significant area of interest and insight in the lives of children, we are committed to developing participatory approaches to research and education that cultivate and harness these ethical insights for the purposes of a collaborative educational experience (as opposed to a focus on "socialization" of ethical virtues). Second, both of our programs use a variety of pedagogical methods to make ethical and philosophical concepts concrete and accessible for young children (including 3-5 year olds). These methods include the shared use of stories, puppets, drawings, and games and extension activities intended to "scaffold" and help children become active participants in the educational process. Third, our projects are collectively concerned with the adult's role in supporting (or hindering) education and philosophical dialogue with children. Both of our programs focus on placing participating children at the center of the educational process as active participants and developers of content that, in turn, forms the basis of dialogue and program lessons. The adult educator and researcher acts as facilitator and guide to this process. Thus, for example, our lessons on various virtues (respect, generosity, etc.) and ethical concepts (fairness, empathy, etc.) are concerned with developing and working from children's own understanding(s) of these dimensions of ethical life.

Over the course of the development of our research projects we have used different, but related, research tools (primarily in the area of qualitative research, using tools such as classroom observation, background questionnaires, semistructured interviews, transcription, and coding). Going forward, our plans are to 
melarete and peech: preface to an international philosophy with children collaboration

more directly combine our research in schools. To begin, this will be achieved through the translation of PEECh lessons (this process is already underway) and research measures ${ }^{7}$ that will then be introduced into four Verona pre-school classrooms (two classes will be included as the education group and two classes will be included as the control/waitlist group) in winter 2016 and spring 2017. The authors will work together in Verona to transcribe, code, and analyze all transcripts from the study. To facilitate this process, our research team just received an International Research Collaboration Grant from the University of Verona, awarded for the purposes of developing this collaboration.

\section{references}

ARENDT, H. The Life of the Mind, New York, NY: Harcourt Brace Jovanovich, 1978.

ARENDT, H. The Human Condition. Chicago, IL: The University of Chicago, 1958

ARISTOTLE. The Nicomachean Ethics. Loeb Classical Library, 1982. Disponible in: https://www.loebclassics.com/view/aristotle-nicomachean_ethics/1926/pb_LCL073.3.xml. Accessed in: 28 dez. 2016.

BACKMAN, Y.; HAGLUND, L.; PERSSON, A; GARDELLI, V. (unpublished). Philosophy with Children: Moral Argumentation and the Role of Pictures.

COPELAND, M. Socratic Circles. Portland, MI: Stenhouse Publishers, 2005.

DEWEY, J. Experience and Education. New York: MacMillan, 1938.

Gardner, S. T. Teaching Children to Think Ethically, Analytic Teaching and Philosophical Praxis, 32(2), 75-81, 2012.

LONE, J. M., \& Burroughs, M. D. Philosophy in education: Questioning and dialogue in schools. Latham, MD: Rowman \& Littlefield, 2016.

MORTARI, L. Caring for the Life of the Mind/Aver cura della vita della mente. Milano: RCS La Nuova Italia, 2002.

MORTARII, L. The Research for Children/La ricerca per i bambini. Milano: Mondadori, 2009.

MORTARI, L. Filosofia della cura. Milano: Raffaello Cortina, 2015.

NODDINGS, N. Caring. Berkeley: University of California Press, 1984.

NUCCI, L. P. Education in the moral domain. London: Cambridge University Press, 2001.

RICOEUR, P. Etica e morale. Brescia, Italy: Morcelliana, 2007.

RUSSELL, B. The Problems of Philosophy. Los Angeles, CA: Enhanced Media, 2016.

SCHLEIFER, M.; DANIEL, M-F.; PEYRONNET, E.; LECOMTE, S. The Impact of Philosophical Discussions on Moral Autonomy, Judgment, Empathy and the Recognition of Emotion in five year olds. Thinking, 16(4), p. 4-12, 2003.

SMETANA, J. G., JAMBON, M, \& BALL, C. The Social Domain Approach to Children's Moral and Social Judgments. In KILLEN, M; SMETANA, J. G. (Eds.) Handbook of Moral Development.

$2^{\text {nd }}$ ed. New York: Psychology Press, 2014. p. 23-45.

received in: 28.12 .2016

accepted in: 22.01.2017

\footnotetext{
${ }^{7}$ Measures used for this combined study include: classroom observations, child interviews, teacher interviews, teacher background questionnaire, parent background questionnaire, and the Head Start Social Competence Scale (all measures will be introduced both pre- and post-intervention).
} 